\title{
KEBIJAKAN RESCEDULING DALAM PERSPEKTIK HUKUM ISLAM
}

\author{
Lely Ana Ferawati Ekaningsih ${ }^{1}$, M. Khozin Kharis ${ }^{2}$, Joharul Fathoni ${ }^{3}$ \\ Institut Agama Islam Darussalam Blokagung Banyuwangi \\ Email: lafwens@gmail.com¹,khozinkharis@gmail.com², \\ joharulfathini14@gmail.com ${ }^{3}$
}

\begin{abstract}
This study aims to determine the policy process of rescheduling as one of the efforts to handle problematic financing and Islamic legal views, especially the Islamic economy towards rescheduling policy as one of the efforts to handle problematic financing in BMT UGT Sidogiri Capem Pesanggaran Banyuwangi district. This type of research is a case study that is testing in detail against one background or one subject or one document storage or a particular event with research data collected both from interviews, observations, and documentation with interactive model analysis. The results of the research show that the policy of distillation is one way to handle problematic financing, where the problem conditions that exist in BMT arise from various aspects, both from the aspects of customers, employees, and nature. Besides that, the rescheduling process at BMT UGT Sidogiri Pesem Pesanggaran is by the procedures and provisions of sharia using the kafalah agreement and Standard Operating Procedure (SOP) that is in the cooperative or non-cooperative.
\end{abstract}

Keywords: Problematic Financing, Rescheduling, Islamic Law Perspective.

\begin{abstract}
Abstrak
Penelitian ini bertujuan untuk mengetahui proses kebijakan resceduling sebagai salah satu upaya penanganan pembiayaan bermasalah dam pandangan hukum Islam khususnya ekonomi Islam terhadap kebijakan resceduling sebagai salah satu upaya penanganan pembiayaan bermasalah di BMT UGT Sidogiri Capem Pesanggaran kabupaten Banyuwangi. Jenis penelitian yang digunakan adalah studi kasus yaitu pengujian secara rinci terhadap satu latar atau satu orang subjek atau satu tempat penyimpanan dokumen atau satu peristiwa tertentu dengan data-data penelitian yang dikumpulkan baik dari hasil wawancara, observasi maupun dokumentasi dengan analisis interaktif model. Hasil penelitian menunjukkan bahwa kebijakan resceduling merupakan salah satu cara untuk menangani pembiayaan bermasalah, dimana kondisi permasalahan yang ada pada BMT muncul dari berbagai aspek, baik dari aspek nasabah, pegawai maupun aspek alam. Selain itu proses resceduling di BMT UGT Sidogiri Capem Pesanggaran sudah sesuai dengan tatacara dan ketentuan syariah dengan menggunakan akad kafalah dan Standard Operating Procedur (SOP) yang ada pada koperasi ataupun non koperasi.
\end{abstract}

Kata Kunci: Pembiayaan Bermasalah, Resceduling, Perspektif Hukum Islam 


\section{A. Pendahuluan}

Baitul Māl wat Tanwil merupakan salah satu lembaga keuangan syariah di Indonesia yang mana pada saat ini sudah cukup banyak diminati oleh kalangan masyarakat khususnya menengah kebawah, dari segi namanya "Baitul Māl" berarti lembaga sosial yang bergerak dalam bidang penggalangan zakat, infaq, shadaqoh dan dana sosial lainya, sertamenyalurkanuntuk kepentingansosial secara berpola dan berkesinambungan. Sedangkan "Baitul Tanwil” inibergerak dalam penggalangan dana masyarakat dalam bentuk simpanan sertameyalurkan dana dengan bentuk pinjaman atau pembiayaan usaha dengan sistemjual beli, bagi hasil maupun jasa (Erfan, 2018:11).

Keberadaan Baitul Māl wat Tanwil diharapkan dapat menjadi sarana bagi masyarakat menengah kebawah untuk peminjaman modal usaha kecil ataupun investasi dana, BMT juga memiliki sistem dan prosedur yang harus dipenuhi untuk investasi dana dan peminjaman modal, akan tetapi sistem dan prosedur yang ditetapkan BMT tidak serumit sistem dan prosedur di perbankan, hal ini terjadi karena BMT didirikan untuk membantu masyarakat menengah ke bawah agar lebih mudah untuk melakukan investasi dana dan peminjaman modal usaha (Erfan, 2018:12).

Ali mengatakan dalam buku Walfajri Maizal (2019:45) mengungkapkan bahwa dalam laporan keuangan KSPS Sidgori tahun 2018, disampaikan bahwa koperasi terus mengalami pertumbuhan. Jumlah anggota mencapai 18.060 orang dengan nilai aset Rp. 2,25 triliun. Selain itu Ali mencatatkan simpanan anggota tahun 2018 sebesar Rp 392,7 miliar dan tabungan Rp1,474 triliun. Adapun pembiayaan yang disalurkan mencapai Rp. 1,03 triliun. Koperasi ini juga memiliki 278 kantor cabang di 10 provinsi. Produk BMT UGT Sidogiri Capem Pesanggaran Kabupaten Banyuwangi secara umum ada tiga kondisi yang pertama berbasis Bagi Hasil, kedua berbasis Jual Beli, ketiga Berbasis Ijarah/Sewa. Didalam penerapan akad pembiayaan BMT mengikuti fiqhi empat madzhab sekalipun dalam kondisi tertentu harus talfiq.Hal ini dilakukan demi kemaslahatan dan memenuhi tuntutan kondisi pasar, sehingga sistem ekonomi syariah bisa diterapkan dan mudah dipahami oleh masyarakat (Chasan, 2019:18). 
Menurut Ali dalam buku Walfajri Maizal (2019:89) pembiayaan bermasalah merupakan pembiayaan yang tidak lancar, pembiayaan dimana anggotanya tidak memenuhi persyaratan atau tidak menepati jadwal angsuran, pembiayaan yang memiliki potensi merugikan BMT dan memiliki potensi menunggak dalam satu waktu tertentu. Hampir semua lembaga keuangan baik bank maupun non bank pernah mengalami permbiayaan bermasalah seperti juga yang terjadi di BMT UGT Sidogiri Capem Pesanggaran Kabupaten Banyuwangi.

Terjadinya pembiayaan bermasalah tersebut dapat diakibatkan dari beberapa faktor diantaranya yaitu faktor dari pihak BMT UGT Sidogiri Capem Pesanggaran yang kurang teliti dalam memberikan pembiayaan, analisis yang dilakukan kurang tepat, tidak meneliti berkas secara maksimal dan mensurvei secara baik. Adapun faktor dari nasabah pembiayaan itu sendiri dimana kondisi usahanya lagi turun, banyaknya berhutang ditempat lain, adanya bencana alam, dan adanya i'tikad yang kurang baik dari nasabah.Wijayanti (2018:67) menyatakan bahwa pelaksanaan Resceduling dapat menjadi suatu cara yang efektif dikarenakan sifatnya yang tidak memaksa keadaan nasabah dan pelaksanaannya sesuai dengan permohonan nasabah bermasalah itu sendiri tanpa adanya paksaan. Resceduling (penjadwalan kembali) merupakan perubahan syarat kredit yang hanya terbatas pada perubahan jadwal pembayaran atau jangka waktu, termasuk masa tenggang baik meliputi perubahan besarnya angsuran maupun tidak. Dari hasil latar belakang masalah diatas maka fokus penelitian ini membahas tentang bagaimana kebijakan resceduling sebagai salah satu upaya penanganan pembiayaan bermasalah dalam perspektik hukum Islam, khususnya hukum ekonomi Islam di BMT UGT Sidogiri Capem Pesanggaran Kabupaten Banyuwangi.

\section{B. Landasan Teori}

\section{Fiqh Muamalah}

Dalam konsep fiqh muamalah penelitian ini menggunakan konsep jual beli, landasan traksaksi jual beli, syarat dan rukun jual beli, bentuk jual beli, konsep taqlid, pendapat ekonomi Islam. 
1. Pengertian Jual Beli

Jual beli atau perdagangan dalam istilah fiqh disebut al-bai' yang menurut etimologi berarti membandingkan sesuatu dengan sesuatu yang lain. Sedangkan secara terminologi adalah mempermilikan sesuatu harta pada orang lain dengan adanya tukar menukar sesuatu dengan mendapat izin syara', atau mempermilikan manfaat selamanya yang diperbolehkan syara' dengan pembayaran harga berupa harta (As Saqof, 2007:679-680).

2. Landasan Hukum Transaksi Jual beli

Al-Qur'an Firman Allah SWT dalam Al-Qur'an Surat An-Nisa' ayat : 29

Artinya : Hai orang-orang yang beriman, janganlah kamu saling memakan harta sesamamu dengan jalan yang batil, kecuali dengan jalan perniagaan yang Berlaku dengan suka sama-suka di antara kamu. dan janganlah kamu membunuh dirimu. Sesungguhnya Allah adalah Maha Penyayang kepadamu (Departemen Agama RI, 2012:83).

Ayat di atas menjelaskan bahwa kita dilarang untuk memakan harta sesama muslim dengan cara yang batil karena dalam konsep jual beli yang harus diperhatikan adalah saling ridho dalam menjual dan membeli barang yang ada. Selanjuntnya dalam ayat di bawah ini juga diharamkan bertransaksi dan memakan harta dengan carariba sebagaimana firmannya dalam Q.S. Al-Baqarah ayat 275.

Artinya : Orang-orang yang makan (mengambil) riba tidak dapat berdiri melainkan seperti berdirinya orang yang kemasukan syaitan lantaran (tekanan) penyakit gila. Keadaan mereka yang demikian itu, adalah disebabkan mereka berkata (berpendapat), sesungguhnya jual beli itu sama dengan riba, padahal Allah telah menghalalkan jual beli dan mengharamkan riba, orang-orang yang telah sampai kepadanya larangan dari Tuhnnya, lalu terus berhenti (dari mengambil riba), maka baginya apa yang telah diambilnya dahulu (sebelum datang larangan); dan urusannya (terserah) kepada Allah. orang yang kembali (mengambil riba), maka orang itu adalah penghuni-penghuni neraka; mereka kekal di dalamnya (Departemen Agama RI, 2012:47).

Ayat ini menjelaskan bahwa Allah SWT menyatakan memberi sedekah kepada orang yang berutang yang tidak sanggup membayar utangnya adalah lebih baik. Jika orang-orang yang beriman telah mengetahui perintah itu, 
hendaklah mereka melaksanakannya. Begitu juga menurut hadits Nabi Muhammad bahwa menunda pembayaran hutang bagi orang yang mampu adalah perbuatan dzalim (HR. Bukhori Muslim, 2015:320).

\section{Hadits Nabi SAW}

Hadist di bawah ini menjelaskan bahwa dalam konsep jual beli itu harus saling terima dan rela satu sama lain sesuai dengan syarat dan rukun jual beli karena yang paling ditekankan dalam jual beli adalah konsep maslahah.

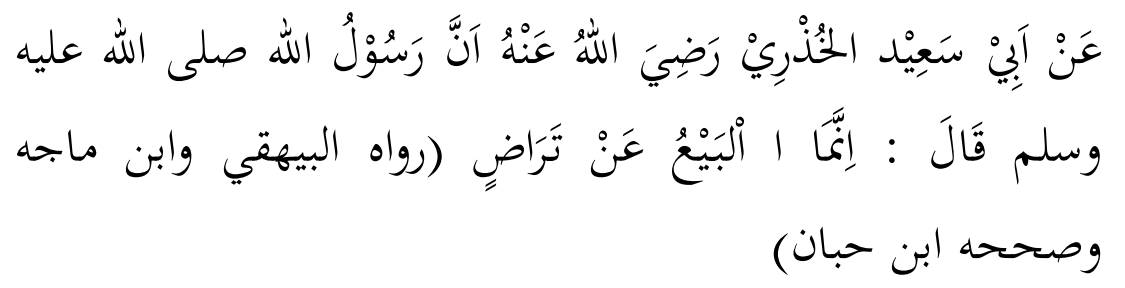

Artinya : Dari Abi Sa'id Al-Khudri bahwa Rasulullah SAW bersabda "sesungguhnya jual beli itu harus dilakukan dengan suka sama suka” (HR. Al-Baihaqydan Ibnu Majahdan dinilai shohih oleh Ibnu Hibban, 2015:609).

3. Syarat dan Rukun Jual Beli

Adapun rukun jual beli menurut ulama Syafi'iyah dalam bahasan fiqh muamalah yaitu ada tiga kriteria yaitu 'aqidain (penjual dan pembeli), ma'qud 'alaih (barang dan harga) dan shighah (ijab dan qabul) (Tim Laskar Pelangi, 2013:12).

4. Bentuk-bentuk Jual Beli

Mazhab Hanafi membagi jual beli dari segi sah atau tidaknya menjadi tiga bentuk, yaitu: jual beli yang sahih, jual beli yang batil, dan jual beli yang fasid (Censerianto, 2011: 23).

\section{Konsep Taqlid dan Talfiq}

Penerapan hukum syariah diperbolehkan memakai mazhab yang telah disepakati para ulama' dengan tujuan untuk mencari kemaslahan dalam hal ini dapat dikenal sebagai taqlid dan talfiq.

a. Definisi taqlid

Secara umum konsep taqlid sangat dibutuhkan dalam setiap kegiatan baik itu ubudiyyah atau muamalah karena pada saat ini sangat tidak dimungkinkan mengetahui dalil-dalil secara detail. 
Artinya: "Taklid adalah melakukan (mengamalkan) pendapat seorang mujtahid tanpa mengetahui dalilnya bahkan jika dia tahu bahwa amalnya sesuai dengan dengan seorang imam maka dia telah taklid padanya" (Bakri, 2015:49).

b. Konsep Talfiq

Dalam konsep penerapan tidak diharuskan untuk mengikuti satu mazhab tapi boleh mengikuti beberapa mazhab karena ada unsur maslahah sebagaimana dasar dalam kitab di bawah ini.

Artinya:"Didalam bab muamalah wajib mengambil pendapat dari semua madzhab yang lebih dekat dengan kemaslahahan umat walaupun harus talfiq, karena dalam muamalah yang ditekankan adalah kemaslahahan manusia"(Azzuhaily, 2017:92).

Dari dasar di atas bisa diambil kesimpulan bahwa pengambilan mazhab itu sesuai dengan kondisi yang dibutuhkan karena tidak selalu dalam satu mazhab itu bisa membahas hukum yang sesuia dengan kondisi yang ada.

\section{Pembiayaan Bermasalah}

Khoirunnisa dkk. (2018:81) pembiayaan bermasalah merupakan keadaan dimana nasabah tidak dapat membayar kewajibannya atau mematuhi jadwal pembayaran angsuran dan tidak memenuhi persyaratan yang terdapat pada akad pembiayaan. Pembiayaan bermasalah ini berdampak pada kerugian bank serta menurunnya pendapatan bank. Ketika debitur tidak memenuhi kewajibannya dalam mengembalikan modal dan menyerahkan porsi keuntungan bank maka pembiayaan akan macet dan risiko pembiayaan atau risiko gagal bayar tersebut akan menimbulkan potensi kerugian bank.

Menurut Hamdan (2015:78), pembiayaan bermasalah adalah suatu kondisi pembiayaan dimana terdapat suatu penyimpangan utama dalam pembayaran kembali pembiayaan yang berakibat terjadi kelambatan dalam pengembalian atau kemungkinan terjadinya kerugian bagi koperasi. Sedangkan menurut Widiyanto bin Mislan Cokrohadisumarto dkk (2016:95) pembiayaan bermasalah adalah pembiayaan yang terdapat tunggakan angsuran pokok atau bagi hasil atau margin .

Pengertian lain menurut Djamil (2012:66) menjelaskan yang dimaksud dengan 
pembiayaan bermasalah adalah pembiayaan yang kualitasnya berada dalam golongan kurang lancar, diragukan, dan macet.

\section{Pengertian Resceduling}

Definisi Resceduling menurut para ahli, seperti yang dikemukakan oleh Ali Hamdan dan Saifuddin (2015:81), Resceduling adalah penjadwalan ulang yang dilakukan dengan mengubah jangka waktu pembiayaan, jadwal pembayaran (penanggalan, tenggang waktu), dan jumlah angsuran. Menurut Muhammad (2010:87), strategi pemulihan dalam usaha mengatasi timbulnya kredit bermasalah pihak lembaga keuangan mikro syariah dapat melakukan beberapa tindakan penyelamatan adalah dengan Resceduling dan reconditioning.

Resceduling dilakukan dalam rangka menyelamatkan pembiayaan debitur karena dalam hal ini mudharib tidak mampu memenuhi kewajibannya dalam membayar angsuran pokok pembiayaan yang telah dijadwalkan, sehingga dilakukan penjadwalan ulang terhadap pelunasan pembiayaan. Hal tersebut disesuaikan dengan proyeksi arus kas (projected cash flow) yang bersumber dari kemampuan usaha debitur (mudharib) (Dewi dan Susilawati, 2017:75).

\section{Penelitian Terdahulu}

Berikut ini adalah hasil penelitian terdahulu yang akan menjadi pandangan, referensi, serta bahan perbandingan dengan penelitian yang saat ini dilakukan antara lain : Penelitian yang dilakukan oleh Muhammad Asyhur tahun 2016 menggunakan metode penelitian deskriptif dengan pendekatan kualitatif. Tujuan penelitian ini untuk mengetahui upaya pencegahan terjadinya pembiayaan bermasalah serta strategi penyelesaian pembiayaan bermasalah pada BMT Amal Mulia Suruh. Hasil penelitian ini yaitu dalam melakukan pencegahan terjadinya pembiayaan bermasalah pada produk pembiayaannya BMT Amal Mulia Suruh melakukan tiga tindakan atau prosedur pokok, yaitu dengan melakukan analisis atau penilaian terhadap permohonan pembiayaan, analisis penilaian pembiayaan yaitu menggunakan prinsip Character (sifat), Capacity (kemampuan), dan Collateral (jaminan), serta yang terakhir dengan pemantauan penggunaan pembiayaan. Namun tidak semua strategi tersebut dapat berjalan dengan baik karena kurang mampunya pihak BMT dalam meramalkan masa yang akan datang 
serta kurang teliti dalam menganalisis permohonan pembiayaan dan persyaratan yang diajukan oleh nasabah.

Penelitian yang dilakukan oleh Muhammad Nuur Rohmaan tahun 2018 merupakan penelitian lapangan (field research) dengan menggunakan deskriptif analitis melalui metode penelitian kualitatif. Berdasarkan hasil penelitian yang didapatkan yaitu pelaksanaan Resceduling dan reconditioning di BMT Bina Sehahtera meliputi beberapa tahap, pertama identifikasi masalah, penyelamatan awal, musyawarah, pemberian surat keputusan tindakan, pembuatan adendum, serta pengawasan dan pembinaan. Dari beberapa prosedur ditemukan ketidaksesuaian dengan aturan hukum yang ada meliputi, tidak terpenuhinya syarat-syarat Resceduling dan reconditioning yang telah dibuat oleh kreditur, debitur dibebani jaminan tambahan di dalam penerapan Resceduling, tidak ada pengkategorian yang jelas dalam pelaksanaan Resceduling dan reconditioning.

\section{Metode Penelitian}

Penelitian ini menggunakan metode kualitatif, dengan jenis penelitian studi kasus dimana sangat tepat digunakan untuk menjawab pertanyaan bagaimana dan mengapa terhadap sesuatu yang diteliti (Yin, 2009:56). Menurut Bogdan dan Biklen dalam bukunya Gunawanan (2015:128) Studi kasus merupakan pengujian secara rinci terhadap satu latar atau satu orang subjek atau satu tempat penyimpanan dokumen atau satu peristiwa tertentu. Surakhmad (2012:56) membatasi pendeketan studi kasus sebagai suatu pendeketan dengan memusatkan perhatian pada suatu kasus secara intensif dan rinci.

Penelitian ini lokasinya di BMT UGT Sidogiri Capem Pesanggaran Kabupaten Banyuwangi. Adapun waktu penelitian berlangsung mulai bulan Mei 2019 sampai dengan bulan Agustus 2019.

Dalam penelitian ini ada dua sumber, yaitu sumbar data primer merupakan data yang secara langsung di peroleh oleh peneliti dari sumber data pertama yang berada dilokasi penelitian atau obyek penelitian (Bungin, 2004:30). Sekunder yang menurut Sumadi Suryabrata (2014:85) data sekunder adalah sumber data yang difungsikan guna memberikan informasi atau data tambahan yang nantinya 
dapat memperkuat data pokok, baik berupa manusia atau benda majalah, buku, Koran. Dalam penelitian ini yang menjadi sumber dari pada data sekunder ini adalah dokumen-dokumen resmi, buku, kitab, hasil-hasil penelitian dan data-data lain yang berkaitan erat dengan penelitian ini.

Prosedur pengumpulan data dilakukan dengan cara mengumpulkan, mengamati dan memformulasikan data primer maupun sekunder yang berkaitan dengan masalah penelitian. Prosedur pengumpulan data dapat diartikan sebagai suatu metode atau cara yang digunakan oleh peneliti guna mendapatkan data yang sebenar-benarnya dan nantinya akan sangat berguna pada hasil penelitian yang dilakukan (Subagiyo, 2017:80). Prosedur pengumpulan data yang digunakan yaitu: Observasi, Wawancara, Dokumentasi.

Alat Analisis Data yang digunakan interaktif model. Miles dan Huberman dalam buku Sugiyono (2007:246), mengemukakan bahwa aktivitas dalam analisis data kualitatif dilakukan secara interaktif dan berlangsung secara terus menerus sampai tuntas, sehingga datanya sudah jenuh. Aktivitas dalam analisis data, yaitu, data reduction, data display, dan conclusion drowing/verification. Analisis data dalam penelitian ini menggunakan model interactive model, yang unsurunsurnya meliputi reduksi data (data reduction), penyajian data (data display), dan conclutions drowing/verifiying. Teknik analisis data pada penelitian ini menggunakan tiga prosedur perolehan data antara lain, yaitu (Sugiyono, 2007:247-252).

\section{Hasil}

Pembiayaan bermasalah merupakan keadaan di mana nasabah tidak dapat membayar kewajibannya atau mematuhi jadwal pembayaran angsuran dan tidak memenuhi persyaratan yang terdapat pada akad pembiayaan (Khoirunnisa dkk.2018:81). Pembiayaan bermasalah berdampak pada kerugian BMT serta menurunnya pendapatan BMT. Ketika debitur tidak memenuhi kewajibannya dalam mengembalikan modal dan menyerahkan porsi keuntungan BMT maka pembiayaan akan macet dan risiko pembiayaan atau risiko gagal bayar tersebut akan menimbulkan potensi kerugian BMT. Sebagaiamana hasil wawancara 
dengan Kepala BMT UGT Sidogiri Capem Pesanggaran Bapak Imron Rosyadi umur (45 tahun) mengatakan:

"Kebanyakan permasalahan disini ini muncul dari bagian pembiayaan, yang mana itu memang murni produk unggulan dari BMT yang ditawarkan. Selama ini, kebanyakan nasabah yang datang ke BMT mereka datang bukan untuk menabung tapi mereka datang itu untuk mengajukan pembiayaan mengembangkan usaha pribadi atau memang untuk membuka sebuah usaha baru, dan dalam dalam BMT perputaran uang yang paling terlihat dalam segi margin itu ya pembiayaan karena dilihat dalam segi margin mulai $1 \%$ sampai 3,5\% sesuai dengan kesepakatan dan akad yang digunakan, tetapi munculnya permasalah itu memang tidak jauh dari produk yang kami tawarkan yaitu pembiayaan, tidak jarang bahkan banyak dari nasabah yang mengalami permasalahan dalam hal angsuran pembiayaan yang telah diajukan.”

Selain dari data wawancara juga diperoleh data lapangan berupa dokumen kolektibilitas nasabah yang mengalami pembiayaan bermasalah yang mempunyai beberapa kriteria mulai dalam BMT baik itu DPK (dalam pengawasan khusus), kurang lancar, diragukan, macet sebagaimana dalam (lampiran tabel kolektibilitas).

Bisa diambil kesimpulan bahwa pembiayaan bermasalah yang ada pada BMT dengan melihat kondisi pada saat ini sudah banyak sekali pembiayaan yang mengalami masalah sehingga bisa meningkatkan nilai Non Perfoming Finance (NPF) pada perusahan, yang berdampak pada nilai jual dan efektifitas perusahaan dalam proses pembiayaan yang bisa dilihat dari data kolektabilitas yang ada berbagai macam kondisi pembiayaan bermasalah dalam BMT baik itu DPK (dalam pengawasan khusus), kurang lancar, diragukan, macet. Pembiayaan bermasalah ini memiliki banyak faktor baik itu memang dari pihak BMT sendiri yang terlalu menganggap remeh kondisi nasabah dalam proses analisa pembiayaan baik itu karena ikatan saudara, temam dekat dll yang mana memberikan celah terjadinya risiko pembiayaan bermasalah.

Faktor yang mempengaruhi pembiayaan bermasalah sehingga harus dilakukan resceduling secara umum ada dua faktor yaitu bisa dari internal BMT bisa dari eksternal baik itu karena alam atau nasabah sendiri. Sebagaimana hasil wawancara dengan Bapak Mujianto (35 tahun) selaku AOAP (Acount Officer Ananlisis Pembiayaan) BMT Sidogiri menjelaskan bahwa : 
"Yang dimaksud dengan kecurangan dalam mengelola pembiayaan itu seperti ini, terkadang kalau nasabah yang mempunyai usaha misalnya dia kemaren bilang, dari usaha yang saya jalankan ini, keuntungan saya bersih bisa mencapai 2 juta. Kalau orang usaha kecil terkadang tidak ada pembukuannya, tentu kita percaya saja padahal waktu itu dia ngakunya ke kita untung, tetapi ternyata dia malah rugi dan mempunyai hutang kepada temannya. Sedangkan si nasabah ini melakukan pembiayaannya bilangnya untuk menambah modal usaha, misalnya untuk beli besi atau usaha yang lainnya, ketika pembiayaan itu di acc pihak koperasi, dan ketika pencairan pihak koperasi menawarkan untuk membeli barang yang diinginkan nasabah, tetapi si calon nasabah malah bilang kalau kemarin dia sudah membeli besi, dan hanya mengambil uangnya dari koperasi. Dari sini kita percaya saja, tetapi pada kenyatanya malah digunakan untuk membayarkan hutangnya ke temannya, tentu kita tidak tahu”.

Rescedulingmerupakan penjadwalan ulang yang dilakukan dengan mengubah jangka waktu pembiayaan, jadwal pembayaran (penanggalan, tenggang waktu), dan jumlah angsuran (Saifuddin, 2015:81).Resceduling dilakukan dalam rangka menyelamatkan pembiayaan debitur karena dalam hal ini mudharib tidak mampu memenuhi kewajibannya dalam membayar angsuran pokok pembiayaan yang telah dijadwalkan, sehingga dilakukan penjadwalan ulang terhadap pelunasan pembiayaan. Hal tersebut disesuaikan dengan proyeksi arus kas (projected cash flow) yang bersumber dari kemampuan usaha debitur (mudharib) (Dewi dan Susilawati, 2017:75). Sebagaimana hasil wawancara dengan Kepala BMT UGT Sidogiri Capem Pesanggaran Bapak Imron Rosyadi (45 tahun) sebagai berikut:

"Pembiayaan bermasalah di sini kebanyakan diselesaikan dengan cara Resceduling, Resceduling ini dilakukan untuk membantu nasabah agar dapat menyelesaikan pembiayaannya tanpa harus menjual asetnya atau pihak koperasi tidak perlu sampai melakukan penyitaan dan pelelangan agunan. Dalam melakukan Resceduling, pihak BMT Sidogiri menanyakan terlebih dulu penyebab tunggakan si nasabah, apakah si nasabah merasa keberatan dengan angsurannya. Sebelumnya juga nasabah disuruh memilih, apakah si nasabah ini mau melunasi sisa kewajibannya pada akhir bulan, atau dilakukan Resceduling, dan terakhir baru menawarkan eksekusi jaminan, tetapi rata-rata nasabah bermasalah, mereka itu lebih memilih dilakukan Resceduling dibandingkan jika jaminannya diambil, jika dari pihak kita akan lebih efektif sebenarnya dengan eksekusi jaminan, dengan jaminan diambil, pembiayaan nasabah yang menunggak akan selesai dan lunas, tapi pihak koperasi tidak setega itu, pihak koperasi melakukannya dengan jalur kekeluargaan dengan menuruti dan melihat kemampuan nasabah terlebih dulu dan yang menjadi dasar kenapa BMT Sidogiri dianggap amam dalam konsep ribawi karena dalam proses resceduling BMT tidak mengikutsertakan 
margin dalam proses perpanjangan sehingga tidak ada unsur penambahan keuntungan".

Proses resceduling dalam BMT dilakukan ketika terjadi pembiayaan bermasalah dan disini ada perubahan akad ketika memang dari nasabah menghendaki untuk melakukan resceduling untuk meringankan beban nasabah dalam hal angsuran. Pendapat ini sebagaimana disampaikan oleh Kepala BMT UGT Sidogiri Capem Pesanggaran Bapak Imron Rosyadi (45 tahun) sebagai berikut:

"Dalam melakukan Resceduling, pihak BMT Sidogiri menanyakan terlebih dulu penyebab tunggakan si nasabah, apakah si nasabah merasa keberatan dengan angsurannya. Sebelumnya juga nasabah disuruh memilih, apakah si nasabah ini mau melunasi sisa kewajibannya pada akhir bulan, atau dilakukan Resceduling, dan terakhir baru menawarkan eksekusi jaminan, tetapi rata-rata nasabah bermasalah, mereka itu lebih memilih dilakukan Resceduling dibandingkan jika jaminannya diambil, jika dari pihak kita akan lebih efektif sebenarnya dengan eksekusi jaminan, dengan jaminan diambil, pembiayaan nasabah yang menunggak akan selesai dan lunas, tapi pihak koperasi tidak setega itu, pihak koperasi melakukannya dengan jalur kekeluargaan dengan menuruti dan melihat kemampuan nasabah terlebih dulu dan yang menjadi dasar kenapa BMT Sidogiri dianggap amam dalam konsep ribawi karena dalam proses resceduling BMT tidak mengikutsertakan margin dalam proses perpanjangan sehingga tidak ada unsur penambahan keuntungan".

Pendapat ini sesuai dengan pendapat Bapak Akyar Syafa'at (28 tahun) selaku

Kepala Sekolah Unggulan MADIN AL-Amiriyah, mengatakan:

"konsep ribawi itu muncul ketika ada unsur barang-barang ribawi seperti emas dan perak, makanan pokok, dan mata uang. Memang dalam BMT disini yang dilakukan berhubungan dengan barang ribawi, tapi dalam yang membedakan di BMT Sidogiri itu diberlakukan akad yang sesuai dengan hukum syara' sehingga ini yang membedakan kenapa BMT aman dari ribawi dan dalam hal perubahan akad di dalam Islam memang ada hukum mengenai taqlid dan talfiq, hukum ini diperbolehkan ketika memenuhi syarat dan rukunnya, dikarenakan yang paling penting dalam Islam itu nilai maslahah yang tidak meninggalkan nilai Islam yang ada selain kebayakan sekarang koperasi bebasis syariah itu sudah menganut semua konsep hukum muamalah apalagi BMT Sidogiri yang sudah terkenal dLm bidang figh"

Hal ini sesuai dengan penerapan hukum syariah yang diperbolehkan memakai mazhab yang telah disepakati para ulama', dalam hal ini dapat dikenal sebagai taqlid dan talfiq.Secara umum konsep taqlid sangat dibutuhkan dalam setiap 
kegiatan baik itu ubudiyyah atau muamalah karena pada saat ini sangat tidak dimungkinkan mengetahui dalil-dalil secara detail.

Dalam konsep penerapan tidak diharuskan untuk mengikuti satu mazhab tapi boleh mengikuti beberapa mazhab karena ada unsur maslahahsebagaimana dasar dalam kitab di bawah ini.

Artinya:"Didalam bab muamalah wajib mengambil pendapat dari semua madzhab yang lebih dekat dengan kemaslahahan umat walaupun harus talfiq, karena dalam muamalah yang ditekankan adalah kemaslahahan manusia"(Azzuhaily, 2017:92).

Dari dasar di atas bisa diambil kesimpulan bahwa pengambilan mazhab itu sesuai dengan kondisi yang dibutuhkan karena tidak selalu dalam satu mazhab itu bisa membahas hukum yang sesuia dengan kondisi yang ada.

\section{E. Pembahasan}

Dari hasil penelitian pembiayaan bermasalah merupakan pembiayaan yang tidak menepati janji dalam pembayaran, sehingga memerlukan tindakan hukum untuk menagihnya. Oleh karena itu, pembiayaan bermasalah adalah pembiayaan yang berpotensi merugikan bank sehingga berpengaruh terhadap tingkat kesehatan bank.Kualitas pembiayaan yang tergolong bermasalah terdapat pada kategori Kurang Lancar, Diragukan, dan Macet. Pembiayaan dengan kualitas ini disebut juga pembiayaan wanprestasi atau pembiayaan bermasalah yang dikenal dengan istilah NPF (Non Performing Financing) (Khoirunnisa dkk., 2018:81).

Pembiayaan bermasalah ini berdampak pada kerugian BMT serta menurunnya pendapatan BMT. Ketika debitur tidak memenuhi kewajibannya dalam mengembalikan modal dan menyerahkan porsi keuntungan BMT maka pembiayaan akan macet dan risiko pembiayaan atau risiko gagal bayar tersebut akan menimbulkan potensi kerugian BMT.

Dari beberapa produk yang ada pada BMT Sidogiri yang paling rawan terjadi permasalahan adalah produk pembiayaan. Dilihat dari hasil wawancara dan tabel kolektibilitas nasabah, ternyata dalam proses pembiayaan bermasalah itu ada berbagai faktor : 
1. Perilaku Nasabah

Gejala pembiayaan bermasalah yang muncul dalam kategori diantaranya yaitu kesehatan usaha nasabah memburuk, terjadi sengketa rumah tangga, telepon dari bank sering tidak dijawab, nasabah mempunyai kegiatan tertentu atau terkena musibah, dan lain sebagainya.

\section{Faktor Internal BMT Sidogiri}

Sebagaimana dari hasil verifikasi data di atas bisa dilihat bahwa permasalahan yang paling banyak di BMT adalah pembiayaan, dilihat dari jumlah data keseluruhan BMT mencapai 7000 nasabah, dari semua nasabah ini yang mengalami masalah dalam proses pembiayaan perkiraanmencapai $20 \%$ dari keseluruhan baik itu dalam pengawasan khusus, kurang lancar, diragukan, macet.

BMT UGT Sidogiri Capem Pesanggaran pelaksanaan resceduling sebagai salah satu penanganan pembiayaan bermasalah dengan berbagai pertimbangan baik itu dari nasabah atau pihak BMT sendiri. Pembiayaan bermasalah di sini kebanyakan diselesaikan dengan cara rescheduling, rescheduling ini dilakukan untuk membantu nasabah agar dapat menyelesaikan pembiayaannya tanpa harus menjual asetnya atau pihak koperasi tidak perlu sampai melakukan penyitaan dan pelelangan agunan. Dalam melakukan rescheduling, pihak BMT Sidogiri menanyakan terlebih dulu penyebab tunggakan pada nasabah, apakah nasabah merasa keberatan dengan angsurannya. Sebelumnya juga nasabah disuruh memilih, apakah nasabah ini mau melunasi sisa kewajibannya pada akhir bulan, atau dilakukan rescheduling, dan terakhir baru menawarkan eksekusi jaminan, tetapi rata-rata nasabah bermasalah, mereka itu lebih memilih dilakukan rescheduling dibandingkan jika jaminannya diambil, jika dari pihak kita akan lebih efektif sebenarnya dengan eksekusi jaminan, dengan jaminan diambil, pembiayaan nasabah yang menunggak akan selesai dan lunas, tapi pihak koperasi tidak setega itu, pihak koperasi melakukannya dengan jalur kekeluargaan dengan menuruti dan melihat kemampuan nasabah terlebih dulu.

Dari hasil data lapangan bahwa proses resceduling dilakukan dengan berbagai tahapan sesuai dengan ketentuan SOP BMT Sidogiri, dalam proses ini sangat 
menentukan apakah resceduling ini sudah berjalan sesuai dengan aturan syariah atau belum. Dengan merujuk berbagai referensi dan data lapangan menunjukaan bahwa proses resceduling pada BMT Sidogiri sudah memenuhi konsep muamalahyaitu menggunakan akad kafalah yang sesuai dengan hukum syariah, dilihat dari berbagai sudut pandang.

Sistem yang ada dalam proses resceduling ini kenapa dianggap sesuai hukum syariah karena disini dalam proses perpanjangan, yang dipertimbangkan adalah unsur margin, dimana BMT Sidogiri tidak menyantumkan margin yang mengendap dalam proses pembiayaan resceduling. Rata-rata nasabah bermasalah lebih memilih dilakukan rescheduling dibandingkan jika jaminannya diambil, jika dari pihak kita akan lebih efektif sebenarnya dengan eksekusi jaminan, dengan jaminan diambil, tapi pihak koperasi tidak setega itu, pihak koperasi melakukannya dengan jalur kekeluargaan dengan menuruti dan melihat kemampuan nasabah terlebih dulu.

\section{F. Kesimpulan}

Proses resceduling diBMT UGT Sidogiri Capem Peasanggaran memiliki prosedur dan SOP yang sudah sesuai dengan standart pendjadwalan ulang di koperasi dan bank yang ada, mulai dari penanganan khsusus pada nasabah sampai penyelesaian pembiayaan yang bermasalah. Semua prosedur restrukturasi atau resceduling sudah ada penjelasan secara detail diawal ketika ada minat dari nasabah salain itu juga ada buku panduan khusus dari BMT berupa SOP yang bisa buat wacana bagi nasabah ketika mengalami permasalahan dalam proses penabungan atau pembiayaan.

Dalam proses resceduling sangat memiliki dampak positif untuk lembaga keuangan dikarenakan mampu mengurangi nilai NPF (Non Performing Financing) sehingga bisa meminimalisir terjadinya likuiditas lembaga serta kemacetan dalam proses pembiayaan karena banyaknya catatan hitam (blacklist) oleh nasabah yang mengalami permasalahan dalam hal pembiayaan (wanprestasi). Selain itu proses resceduling pada BMT Sidogiri sudah melaui beberapa prosedur dan akad yang sesuai dengan hukum syari'ah dan yang paling ditekankan dalam 
proses ini BMT tidak mengikutsertakan margin pembiayaan yang lama dalam proses resceduling sehingga tidak muncul ilat riba yaitu ma'lum tafaddlul, dan akad yang digunakan juga sudah sesuai dengan konsep muamalah dengan menggunakan akad kafalah sebagai mana dalam kitab fiqhul Islami dan syarah muhaddab.

Penelitian ini bisa dijadikan bahan rujukan ketika menemukan permasalah dalam proses pembiayaan baik dalam proses pendekatan, analisis dan penyelesaian masalah sehingga mempunyai banyak variasi dan variabel kira-kira apa yang menjadi sumber pokok nasabah mengalami permasalahan dalam proses pembiayaan.

\section{Daftar Pustaka}

Al-Quran, 2012. Departemen Agama RI. Jakarta: Word Press.

Arikunto. 2007. Metode Penelitian Kualitatif. Surabaya: Pustaka Media.

As Saqof. 2007. Formulasi Fiqh Muamalah konteporer. Jakarta. DKI Bairut.

Asyhuri, Muhammad. 2013. Strategi Penyelesaian Pembiayaan Bermasalah pada Produk Pembiayaan di BMT Amal Mulia Suruh" (Tugas Akhir-STAIN Slatiga).

Azzuhaily, Wahbah. 2012. Fiqih Islam wa addilahu jilid V. Jakarta: DKI Bairut. Bakri, Syatha Sayid. 2015. Ianatut Tholibin. Jakarta: DKI Bairut.

Bungin. 2004. Metode Penelitian Kualitatif. Jakarta: Gema Insani.

Censerianto. 2011. Konsep Jual Beli Islam. Jakarta: Word Press.

Cokrohadisumarto dkk. 2016. Pembiayaan Syariah. Bandung: Gema Insani.

Djamil. 2012. Koperasi Syariah. Yogyakarta: Word Press.

Maizal, Walfajri. 2019. Penyelamatan Pembiayaan Dalam Koperasi. Jakarta. Word Press.

Erfan. 2018. Pedoman BMT Sidogiri. Pasuruan: Sidogiri Press.

Hamdan, Ali dan Saifudin. 2015. Penjadwalan Ulang Perbankan Syariah. Yogyakarta: Puri Sata.

Hamdan. 2015. Strategi Pembiayaan Koperasi. Jakarta: Togas Mas

Juliansah, Noor. 2015. Metode Penelitian Kualitatif. Bandung: Gema Insani.

Khoirunnisa dkk. 2018. Konsep Pembiayaan Bermasalah. Surabaya: Gramedia Press.

Lexy, J. Moleong. 2007. Metodologi Penelitian Mix. Jakarta: Gramedia Press.

Muhammad. 2010. Perencanaan Bank Konvensional. Surabaya: Pustaka maharani press.

Muslim, Bukhori. 2015. HR. Bukhori Muslim. Jakarta: DKI Bairut.

Rohmaan, Muhammad Nuur. 2018. Pelaksanaaan Rescheduling dan Reconditioning terhadap Nasabah Wanprestasi pada Perjanjian Pembiayaan dengan Jaminan Fidusia di BMT Bina Sejahtera Sleman. 
Sekaran, Uma. 2007. Metode Penelitian Kualitatif dan Kuantitatif. Surabaya: Sinar Grafika.

Sugiyono. 2007. Metode Penelitian Kualitatif. Jakarta: Pustaka Media.

Tim Laskar Pelangi. 2013. Fiqh Konteporer. Kediri: Lirboyo Press.

Wawancara dengan Bapak Akyar Syafa'at Kepala Madin Unggulan Al-Amiriyyah Darussalam Blokagung 24 Juli 2019, jam 08.00 WIB.

Wawancara dengan Bapak Imron Rosyadi kepala BMT UGT Sidogiri Capem Pesanggaran 21 Juli 2019, jam 09.00 WIB.

Wawancara dengan Bapak Yusuf kasir BMT UGT Sidogiri Capem Pesanggaran 23 Juli 2019, jam 11.00 WIB.

Wijayanti. 2018. Pedoman Rekontruksi Bank dan Non Bank. Bandung: Garuda Muda.

Yin. 2009. Metode Penilitian Kualitatif. Jakarta: Gramedia. 